\title{
ST. BARTHELEMY IN DEN ZWEEDSCHEN TIJD
}

\author{
I \\ DOOR \\ P. DE BARBANSON O. P.
}

De laatste Zweedsche gouverneur heeft, vóór het eiland aan de Franschen overging, een overzicht van de geschiedenis van het eiland in den Zweedschen tijd samengesteld. Van dit overzicht is een uittreksel in het Engelsch gemaakt, ${ }^{1}$ ) en daarvan is een Fransche vertaling in eenige exemplaren op het eiland aanwezig. Dat door dit overschrijven onnauwkeurigheden zijn ingeslopen, vooral in de cijfers (het bevolkingscijfer 5000 voor het jaar 1800 is niet waarschijnlijk), ligt voor de hand, maar niettemin leek mij een gedeelte van dit stuk, dat aanknoopt bij de geschiedenis van St. Eustatius, voor de lezers van dit tijdschrift van belang. Wat hier volgt is geen letterlijke vertaling; ik heb verband gelegd tusschen de opvolging der gebeurtenissen, maar meen, dat voldoende te onderkennen is, waar dit is geschied.

Was het in de jaren na de eerste helft der 18de eeuw met onze bovenwindsche eilanden mis, bij de Franschen was dit niet anders. En roept in onze geschiedenis het woord „West-Indische compagnie" nu niet juist herinneringen aan overvolle geldbuidels op, het kan tot troost strekken, dat de Franschen en de Zweden ook hun twee West-Indische compagnieën hebben gehad, en evenmin uit weelde maar in de hoop, dat ze de tweede maal gelukkiger zouden zijn dan den eersten keer.

De bestuursgeschiedenis van de Fransche eilanden loopt echter niet evenwijdig met die van onze West-Indische eilanden, want behalve compagniebestuur en régime des Grands seigneurs en der Malthezer ridders zijn de Fransche koning en de Fransche staat achtereenvolgens bezitters geweest. En de kleine kolonie St. Barthélémy huppelt mee in de geschiedenis achter de politieke sprongen van haar grootere zuster Guadeloupe, tot de Franschen

1) Het is niet geheel onmogelijk, dat het oorspronkelijk stuk in het Engelsch is geschreven geweest.

West Indische Gids XVII 
het loslieten als lastpost, die nu eenmaal door hen niet productief scheen gemaakt te kunnen worden.

Als het zoo ver is, in 1784, welk een geschiedenis hebben St. Eustatius en St. Kitts, ja ook St. Martin, de naaste buren van St. Barthélémy, dan al niet achter den rug. Honderden kapiteins hebben deze wateren bevaren, maar hoe weinigen hadden St. Barthélémy tot bestemming? Het was een eiland van eenige arme Normandische boeren, hokvaster dan de andere Europeanen in de West, welke laatste als het hun hier niet naar den vleeze ging, elders hun fortuin zochten. Ubi bene ibi patria was de stelregel van toen, en het „dierbaar plekje grond” is een uitvinding van later. De St. Barths-lui hielden zich buiten handel en verkeer, ook vlak in de buurt deden zij daaraan niet, en niet eens op hun eigen eiland. In den Amerikaanschen vrijheidsoorlog lieten zij de leveranties van oorlogstuig dan ook maar aan St. Eustatius over, dat daarvan de vruchten plukte, toen in 1779 wel 3500 schepen op de reede lagen, maar twee jaar later zich door een Engelsche oorlogsvloot voor goed geplunderd en gebrandschat zag.

De Zweden lieten zich hierdoor niet ervan afschrikken een steunpunt in de West te zoeken, maar zij konden zich er niet over verwonderen, dat zij niet meer dan een opgegeven eilandje konden krijgen, en de verkoopers trokken zich niet terug uit de West. In 1783 trok koning Gustaaf III van Zweden naar Rome om met den Paus eenige zaken te regelen; hij slaagde tot beider voldoening, en dat gaf hem moed om op de thuisreis Parijs aan te doen, waar het hem gelukte een overeenkomst geteekend te krijgen, waarbij St. Barthélémy werd afgestaan aan Zweden. In een brief van 8 Juli 1784 meldde de Koning dit aan zijn regeering.

Op 7 Maart 1785 werd het eiland door ridder Durat, den gouverneur van Fransch St. Martin en St. Barthélémy, overgedragen aan den Zweedschen gouverneur baron S. M. Rüyalin, die zich op het eiland vestigde met dr. Fahlberg als gouvernementssecretaris, S. Thunberg als predikant en P. H. Rosenstein als garnizoenscommandant. Het eiland had toen 739 bewoners, van welke 458 blanken waren en 281 negers. De blanken waren grootendeels Franschen, maar ook kwamen wel Engelschen en Hollanders onder hen voor, de drie naties dus, die men in dien tijd op alle kleine eilanden in de „Caribbean” bij elkaar vindt, en die ook heden ten dage de eenige Europeanen zijn, die in de West bezittingen hebben. Er waren toen niet meer dan 9 landbouwers op het eiland, en het levensbestaan werd door de bevolking hoofdzakelijk gezocht in vischvangst, kalkbranden en veeteelt. De 
uitvoer van suiker, ruwe katoen en verdere producten bedroeg jaarlijks 4 scheepsladingen (vergelijkt daarbij St. Eustatius met zijn 3500 schepen!).

L'Orient, dat tot nu toe de hoofdplaats was geweest, werd stil in zijn landelijke rust gelaten, en de Zweden gingen hun aandacht besteden aan een andere baai, veel beter gelegen en veiliger schuilplaats biedend voor de schepen in den orkaantijd, en als haven ook beter te beschermen tegenover een vijand, nauw ingesloten als zij was door heuvels. De stad, die zich daar allengs ontwikkelde, noemden de Zweden naar hun koning Gustavia.

Aanstonds werd er flink aangepakt. Den 7den September 1785 werd Gustavia tot vrijhaven verklaard, en op het einde van dat jaar was het bevolkingscijfer gestegen tot de 950 , t.w. 542 vrijen, 408 slaven, en bovendien was er een garnizoen van 52 man. Het begin was er dus, en het was zaak voort te gaan.

In 1790 kwam de garnizoenscommandant Carl Frederik Bagge aan het bestuur als gouverneur; een militair bestuurder was in dien tijd wel gewenscht, want de revolutionaire begrippen drongen op de Fransche Antillen meer en meer door, terwijl menig patriot op St. Barthélémy aan wal stapte om de bevolking tegen het wettig gezag op te zetten. Het kwam zelfs zoo ver, dat de gouverneur versterking van het garnizoen aanvroeg. Ook roerden zich de slaven hier evenals op de andere eilanden in dezen tijd. Het waren de echo's van het „Vrijheid, gelijkheid en broederschap”, dat in Frankrijk gezongen werd. Op St. Domingo gingen de slaven zelfs vechten voor hun vrijheid; ook op Curaçao kwam het in 1795 tot een oproer. Op St. Barthélémy is het tot opstand niet gekomen.

In 1791 kon de gouverneur aan de regeering in Zweden melden, dat Fahlberg een volledige kaart geteekend had van de eilanden St. Barthélémy en St. Martin.

Met rust werd het tot bloei komend eiland echter niet gelaten. In 1793 verklaarden de Engelschen alle schepen, die op St. Barthélémy lading hadden ingenomen, verbeurd, maar de Zweedsche compagnie kocht om zich te verweren in $Z$ weden 300.000 pond kruit, dat op de „Neptunus” werd ingeladen met St. Barthélémy als bestemming. Ook dat mocht niet baten; de „Neptunus" werd genomen en de lading in Londen verkocht.

Als tusschentijdsch gouverneur werd in 1795 de commandant der troepen G. of Troll benoemd. Hij klaagde over de Fransche en Engelsche zeeroovers, die nog maar steeds niet de schepen van en naar het eiland met rust lieten, en terecht klaagde hij, want 
vijf jaren later is er nòg groote onrust onder de bevolking van wege de vele zeeroovers in de naburige zeeën. In de volgende jaren bleef het zoo; daarbij kwam de kans, dat Amerika zijn havens zou sluiten. Maar nòg kwamen er een 400 tot 500 schepen binnenvallen. En de bevolking neemt toe: in 1800 is Gustavia een stad met 5000 inwoners, en de Normandiërs, een 1000-tal, bleven op hun land bij hun kooien, ver buiten alle stads- en haven drukte. Er werden in dien tijd geteld 877 huizen en 32 regenbakken. Er is welvaart gekomen, en het Zweedsche bestuur acht den tijd gekomen om iets van die welvaart in de schatkist te laten vloeien; vandaar dat het een reeks belastingwetten ging uitvaardigen, $\mathrm{nl} .: 1^{\circ}$ een hoofdelijke omslag, $2^{\circ}$ een grondbelasting, $3^{\circ}$ een belasting op de industrieën behalve bakkerijen en slachterijen, $4^{\circ}$ zegel- en successierechten, $5^{\circ}$ een recht op brieven van naturalisatie, paspoorten enz., $6^{\circ}$ een recht op vrijlating van slaven, $7^{\circ}$ een recht bij doopen, trouwen en begraven, $8^{\circ}$ een belasting op slijterijen, billards en openbare vermakelijkheden. Waarschijnlijk werd de onder $7^{\circ}$ genoemde belasting bij de aangifte aan den burgerlijken stand betaald, want in de kasboeken der R. K. kerk staan wel inkomsten voor doop en begrafenis aangeteekend, maar uit niets blijkt, dat de pastoor hier als ontvanger voor de overheid optreedt, terwijl toch ook alle uitgaven nauwkeurig aangeteekend staan, zooals „pour reçevoir mr. l'abbé après la ceremonie des morts, $1^{\text {blle }}$ de bierre $\$ 0.3,1 / 21$ sucre blanc $\$ 0.12$, papier, plumes, pains à Catherine (Pitine) \$0.4. Pitine is de verzorgster van den pastoor geweest; hij noemt haar herhaaldelijk in zijn kasboek. In alle rekeningen vindt men het dollarteeken, maar van dollar werd en wordt hier nooit gesproken; men rekent met een ,gourde" $=$ frcs. $5^{1}$ ).

Dat vele vreemdelingen zich op het eiland vestigden, vond zijn oorzaak in de gemakkelijke naturalisatie. Daarvoor was noodig een verblijf van één jaar, een onbesproken gedrag en het bezit van een bepaald vermogen.

Aan het hoofd van het garnizoen stond een commandant met

1) Men verhaalt den volgende oorsprong van het woord ,gourde": In den ouden tijd was de Spaansche dollar of peso de gangbare munt. Door gebrek aan zilver werd die munt meer en meer gesnoeid en daardoor waardeloos. Echter werd het zilvergehalte weer hersteld en om nu de goede, nieuwe dollarstukken bij de berekening te onderkennen van de waardelooze oude munten sloegen de Spanjaarden er de woorden ,peso-gordo" in, wat de Franschen maakten tot „piastre-gourde”, later kortweg ,,gourde". 
zijn secretaris en een generaal-adjudant (aide-de-camp). Ook het verdere ambtenarencorps was natuurlijk gegroeid, en men vindt vermeld: een dokter, predikant, onder-officier, ingenieur, douanebeambte, ijkmeester.

Het gouvernementeel rapport van 1800 stelt vast, dat de handel de voornaamste factor van volkswelvaart is; de landbouw heeft niet veel vooruitzicht, omdat de grond steenachtig is en er jaarlijks vijf of zes maanden van volstrekte droogte zijn. Alleen de katoencultuur heeft eenig succes. Men kan hieruit deze slotsom trekken: de later gekomen handeldrijvende vreemdelingen worden rijk; de oudere bewoners, de zich van den handel afzijdig houdende Normandiërs op het platteland, blijven arm.

St. Barthélémy gaat vooruit, dank zij de aardrijkskundige ligging van het eiland, want zoo lang Zweden in de zeeoorlogen rondom onzijdig blijven kan, blijft het een wijkplaats voor vreemdelingen. Behalve de oorlogsvluchtelingen konden ook zij, die voor schulden vervolgd werden, hier een vrijplaats vinden voor tien jaar.

Wat de genoemde belastingen betreft - de minister van handel in Zweden was het er niet mee eens. De hoofdelijke omslag zou naar het aantal blanke gezinsleden berekend worden, terwijl op de naburige eilanden een dergelijke hoofdelijke omslag naar het aantal slaven werd opgelegd, en nu vreesde de minister, dat op deze wijze de gedachte van eenige gelijkheid tusschen blanke en slaaf kon opgewekt worden. Ook de belasting op de industrieën achtte hij verkeerd, alsook iedere andere belasting, waardoor de pas aangekomen vreemdelingen hier zwaarder dan elders belast zouden worden, en zij werden dan ook weer ingetrokken.

Voor de gouvernements schatkist maakte dit heel wat uit, want, beurde men in 1797 nog 145.041 gourdes, in 1801 brachten de belastingen niet meer dan 35.874 gourdes op. Er waren in 1800 op het eiland 40 kooplieden, de compagnie bezat drie magazijnen, 3 schepen speciaal voor het vervoer van specerijen, die in $17 \mathrm{za}-$ ken verhandeld werden, er waren 2 verzekeringsagenten, 8 hotels en billardzaken, 22 slijterijen, 6 bakkerijen, 4 slagers, 3 zeilmakerijen, 3 bijoutiers, 1 klokkenmaker, 1 smid, 8 metselaars, 7 scheepstimmerlieden, 9 gewone timmerlui, 2 schrijnwerkers, 6 kleermakers, 3 touwslagers, 1 hoedenfabrikant, 5 scholen.

Kwamen er in 1791512 schepen binnen en het volgend jaar één minder, in 1793 zijn het er 977, in 17941115 , in 17951568 , en het hoogtepunt werd een jaar later bereikt met 1739 schepen; daarna volgt een inzinking: 1797 geeft 1530 schepen, 17981109 en 1799 
weer 1404. Dit laatste jaar werd nog uitgevoerd voor een waarde van 1.657.899 gourdes en ingevoerd voor 335.832 gourdes.

Dit zijn voorzeker allemaal mooie cijfers voor een stad, 13 jaren geleden gesticht op een eiland, dat den naam had van „,kale rots". St. Barthélémy had zich een belangrijke plaats in den handel veroverd, en het geheele jaar door zag men in de haven de vlaggen van Amerikaansche en Europeesche schepen, die van alle oorden der wereld de goederen aanbrachten en daarheen meenamen.

Niet altijd zou het zoo duren. 20 Maart 1801 verscheen een Engelsche vloot voor het eiland. Zweden had deelgenomen aan de neutraliteitsconventie met Rusland, Denemarken en Pruisen, en dit was blijkbaar voor Engeland, ook zonder oorlogsverklaring, voldoende voor vijandelijke maatregelen. De gouverneur Ankarhem liet de alarmklok luiden om de inwoners op te roepen tot verdediging van het eiland. In het geheel kwamen er 20 man uit de stad en 15 van buiten opdagen. Denzelfden dag kwamen de Engelsche brigade-generaal Puller en kapitein King aan land en sommeerden den gouverneur het eiland binnen één uur aan de Engelschen over te geven. De gouverneur riep den krijgsraad bijeen, die samengesteld was uit de $Z$ weedsche officieren en enkele notabelen van Gustavia. Door de militaire overmacht en het lot van St. Eustatius bewogen, besloot men het eiland over te geven. Dit geschiedde den dag daarop in handen van den luitenantgeneraal Frigge en den schout bij nacht Dackworth, den commandant van het Engelsche eskader. Alle Zweden moesten trouw zweren aan den koning van Engeland, maar zij behoefden niet de wapenen op te nemen tegen hun ouden vaderland. De voornaamste autoriteiten, in de eerste plaats de gouverneur, werden krijgsgevangen verklaard, en alle schepen in de haven werden in beslag genomen. De magazijnen van de compagnie werden verbeurd verklaard. De Engelsche kolonel Wilson werd tot gouverneur aangesteld.

De moeilijkheden tusschen Engeland en Zweden werden opgelost, doordat op 7 Juni 1801 Zweden toetrad tot de Petersburgsche conventie. St. Barthélémy keerde aan Zweden terug. De Engelsche gouverneur, toen Cranstown, verliet het eiland op 10 Juli 1802 . De Zweden vonden in de administratie een geweldige wanorde; niets was ook gedaan voor de welvaart van het land. De Zweedsche gezaghebber Trolle rapporteerde aan zijn regeering, dat de Engelschen zich als zeeroovers gedragen hadden en niet eens de voorwaarden der capitulatie in acht genomen 
hadden. Er zat voor de Engelschen niet anders op dan 9000 pond sterling schadevergoeding te betalen.

Het jaar daarop verleende de Koning van Zweden zijn goedkeuring aan het plan om door de vroeger genoemde belastingen een koloniale kas te vormen, die voor havenwerken, herstelling van kaden, regenwaterleidingen en dergelijke werken zou kunnen worden aangewend.

Men kon echter niet tot rust komen. De negers waren woelig, kwamen hier en daar in opstand, en dit had zijn nadeeligen invloed. Ook onder de andere inwoners kwam een misdadig element op: er kwam plotseling zeer veel valsch geld in omloop.

De scholen - dit woord in zijn beteekenis van een eeuw geleden - stonden niet rechtstreeks onder het staatsgezag. Juist in dezen tijd nu ging men ertoe over om een behoorlijk schoolgebouw te stichten.

In de jaren 1805-1806 deden de Europeesche oorlogen zich ook in de Caraïbische zee weer gevoelen. Koning Gustaaf III van Zweden nam in 1805 deel aan de coalitie tegen Napoleon. In de loop van het volgend jaar ontving de gouverneur van Guadeloupe, generaal Ernouf, bericht van de oorlogsverklaring tusschen Frankrijk en Zweden. Hij zond het door aan Ankarhem, den gouverneur van St. Barthélémy, die hij, evenals Villaret, de gouverneur van Martinique, welgezind was, maar Jerôme Bonaparte, commandant van het Fransche eskader in de Antillen, was van andere meening. De Zweedsche handelsvloot, eerst niet lastig gevallen, werd allengs door de Fransche kapers bestookt, en verschillende schepen vielen den vijand in handen. De handel ging aan het kwijnen, en de gouverneur meende een redmiddel te zien in een overeenkomst met het Fransche gouvernement, waarbij hij de onzijdigheid van St. Barthélémy voorstelde. Zoo iets had men ook op St. Martin, waar over en weer onzijdigheid beloofd was,voor het geval Holland en Frankrijk in oorlog zouden komen. Eigenlijk zou men op het $Z$ weedsche eiland liever de zijde van Frankrijk dan die van Engeland gekozen hebben. Ankarhem wendde zich tot de regeering in het moederland, erop wijzende, dat niet alleen de Engelsche kapers maar ook de Engelsche oorlogsschepen voortdurend de Zweedsche schepen, die van Fransche havens kwamen, genomen hadden, en hij verzocht om kruit en manschappen, ten einde de belangen van het eiland te verdedigen.

Vóor het antwoord gekomen was, zond Ankarhem op aandrang van den handel mr. Bergstedt, den president van het hof van justitie, naar Guadeloupe met aanbod van onzijdigheid. Daar 
werd de afgezant verwezen naar den gouverneur van Martinique, die verklaarde het aanbod tot zijn leedwezen te moeten afwijzen.

Het optreden der Engelsche marine werd intusschen steeds ondragelijker. Van het begin van 1807 af kruiste een Engelsch fregat voor de haven van Gustavia en nam alle schepen met bestemming naar St. Martin en St. Eustatius, in die dagen weer en nog in handen der Hollanders, terwijl de Engelschen reeds weer meester op Curaçao waren. Dat kon zoo niet blijven, en de gouverneur van St. Barthélémy beval den garnizoenscommandant een kanonschot in de richting van het fregat af te vuren, echter zonder het te treffen. De gouverneur zond tevens een protest naar den Engelschen eskadercommandant in de Antillen, admiraal Cochrane, waarin hij het onrechtmatige optreden der Engelschen tegen het eiland bestreed. Maar nog in den loop van het jaar werd de toestand geheel anders. Den 12den November 1807 verschenen de Franschen voor het eiland, en de Engelschen snelden te hulp. Cochrane zond de brik „Epervier” om het eiland tegen zijn aanvallers te beschermen. Zoo trad er rust in.

Den 3den October 1811 werd gouverneur Ankarhem vervangen door baron Stakelberg. In een brief van 12 Februari 1812 noemt Ankarhem als reden, dat hij in ongenade gevallen is, het stoken van twee zijner ambtenaren, den reeds genoemden mr. Bergstedt en den gouvernementssecretaris Fahlberg. Deze hadden de openbare gelden verkwist, maar zich aan de gevolgen weten te onttrekken door de schuld op de administratie van den gouverneur te werpen. Dr. Fahlberg ging later in ballingschap, en stierf op 76 jarigen leeftijd den 23sten November 1834 op St. Eustatius.

In 1812 - den 15den April had de nieuwe gouverneur het bestuur aanvaard - verlieten 1793 schepen met uiteenloopende bestemming de haven van Gustavia; dat was nog meer dan in het topjaar 1796. Het was grootendeels de handel van St. Eustatius, toen Engelsch bezit, die St. Barthélémy met St. Thomas tot zich getrokken had.

Er bestond destijds ook kiesrecht. Kiesgerechtigd waren: $1^{\circ}$ de grondbezitters, $2^{\circ}$ Zweden, geboren op het eiland, ten minste 21 jaar oud en geen huispersoneel zijnde, $3^{\circ}$ alle genaturaliseerde $Z$ weden, die niet dienstbaar waren, $4^{\circ}$ alle inwoners, die gedurende 7 jaar op het eiland gevestigd waren en een beroep uitoefenden behalve sjouwerlieden en landarbeiders. De verschillende uitzonderingen wijzen erop, dat men de vrije zwarten zoo veel mogelijk buiten het kiezerscorps wilde houden. Het aantal kiezers wordt niet opgegeven. In Februari 1812 bedroeg de be- 
volking: buiten de stad 933 blanken, 90 vrije kleurlingen en 588 slaven; in de stad: 1025 blanken, 1038 vrijgelatenen en 1818 slaven; te zamen 5492 zielen.

De buitenbevolking was er over het algemeen treurig aan toe. Katoen maakte geen prijs, zoodat de cultuur ervan verwaarloosd werd. Meer legde men zich toe op groenten- en veeteelt. De stadsbevolking van Gustavia stond er met haar handel beter voor.

Gouverneur Stakelberg trof het, dat in Zweden een afzonderlijk departement van koloniën, voor Pomeranie en St. Barthélémy, werd ingesteld. De kolonie zou een eigen begrooting krijgen. Aan dezen gouverneur wordt de eer gegeven, dat hij de eerste gouverneur is geweest, die den juisten toestand van de kolonie aan de regeering in Stockholm heeft voorgelegd.

In hetzelfde jaar 1812 begonnen de Engelschen weer hun rooftochten in de Antillen. De gouverneur Stakelberg beriep zich erop, dat de vrede tusschen Engeland en Zweden geteekend was, maar dat belette den Engelschen geenzins om gedurende het volgend jaar nog lustig voort te gaan op den ingeslagen weg. Sloepen van het Engelsche oorlogsschip „Vestal” vielen zelfs een Zweedsch schip, dat rustig op de reede voor anker lag, aan; zij enterden het en waren reeds bezig met het weg te voeren, toen de kanonnen van de batterij vuur gaven op den vijand, die op de vlucht sloeg en zijn buit in de steek liet.

In Maart 1813 juichten de St. Barthsianen, want Guadeloupe, volgens Stakelberg „la perle des Antilles”, werd door de Engelschen aan de Zweden afgestaan. Men stelde zich veel goeds voor van de onderlinge verhouding, al vreesde Stakelberg, dat Guadeloupe den handel van Gustavia wel eens tot zich zou kunnen trekken. Dit gebeurde niet. 1814 was een jaar van grooten voorspoed, in verband ook met den algemeenen vrede, in Europa teruggekeerd. Holland en Spanje kregen hun bezittingen in de West terug, en men vreesde, dat St. Eustatius zou herleven, maar Gustavia met zijn prachtige haven won het. Echter duurde de vreugde over het bezit van Guadeloupe maar kort, want nog in hetzelfde jaar 1814 kwam het bij het verdrag van Parijs aan Frankrijk terug.

Het volgend jaar kwam een nieuw garnizoen van 60 man uit Zweden onder commando van den kapitein Lorich. Veel administratieve verbeteringen werden aangebracht, en de slavernij werd beter gereglementeerd. Een slaaf had toen nog den marktprijs van 225 gourdes.

Het boterde niet bijzonder tusschen den gouverneur ,,met zijn 
driftig karakter", naar gezegd wordt, en de overige ambtenaren, in het bijzonder niet met den voorzitter van het Hof van Justitie Bergins. Gouverneur Stakelberg hield zich strikt aan de etiquette, en toen Bergins het waagde voor hem te verschijnen zonder pantoffels, gaf hij hem openlijk een berisping. Bergins werd het volgend jaar teruggeroepen en het verder verblijf op St. Barthélémy werd hem ontzegd.

Nieuwe vrees voor concurrentie van St. Eustatius leidde tot verlaging der douanerechten, die met vreugde door de bevolking vernomen werd.

Stakelbergs bestuur eindigde mede in 1816. In Mei van dat jaar werd tot zijn opvolger benoemd luitenant-kolonel Rosensward. In een brief aan een kanselier van het hof heeft Stakelberg in Augustus van dat jaar zich beklaagd over de praatjes, die omtrent hem in omloop zijn gebracht, als zou hij bij den Koning in ongenade zijn gevallen. Hij vroeg een onderzoek naar zijn bestuursdaden.

5 Augustus stapte Rosensward aan wal en vijf dagen later nam hij het bestuur in handen. Rapport op rapport met klachten zond hij aan den koning: het eiland schilderde hij in de somberste kleuren af; het gouvernements-paleis was niet grooter dan de kajuiten van het Engelsche schip, dat hem naar St. Barthélémy had gebracht; het was veel te min voor hem en zijn gezin; wegens geldgebrek vroeg hij zijn salaris vooruit. Maar het bestuur van zijn voorganger roemde hij.

De gouden tijd was voor het eiland voorbij, hoewel de inkomsten de uitgaven nog overtroffen. De handel ging achteruit. Een vergelijking met St. Thomas en St. Eustatius viel nu weer ten nadeele van St. Barthélémy uit.

Rosensward gaf ook bericht van den ongunstigen toestand der vestingwerken en van het garnizoen, waarvan in de laatste jaren er meer dan twintig krankzinnig gestorven waren. Er was geen kruit en er waren geen kanonnen, die hij toch noodig had, om „die verwenschte zeeroovers" te beletten in de haven van Gustavia binnen te komen en daar te ankeren.

Het antwoord, dat hij van de regeering kreeg, was een waarschuwing over zijn fiscaal beleid. Bovendien verloor hij in dezen tijd zijn vrouw.

1818 was iets beter.

Karel XIII werd opgevolgd door Karel XIV. Hem zwoeren ambtenaren en ingezetenen trouw.

Een buitgemaakt Portugeesch schip, geladen met gestolen 
goederen, werd naar Gustavia opgebracht en daar met lading en al verkocht. De gouverneur verklaarde, toen bleek, dat het niet in orde was, dat hij er niets van geweten had, wat een zekere heer Stuart zoo sterk ontkende, dat hij den gouverneur beschuldigde, zelf de hand in het nemen van het schip gehad te hebben. Een vervolging werd ingesteld, en daar Stuart zijn beschuldiging niet bewijzen kon, werd hij veroordeeld, den gouverneur schadevergoeding te betalen en eerherstel te geven. Deze vond de straf veel te licht, en trok zich de geheele gebeurtenis zeer aan. Den 19den September ging hij herstel zoeken op het eiland Nevis, waar hij spoedig aan tering stierf. De gouvernementssecretaris Huns Wolff werd van St. Barthélémy afgevaardigd om de Zweedsche autoriteiten bij de begrafenis te vertegenwoordigen. Burgemeester Berghult, die als vice-gouverneur Rosensward tijdens diens verblijf op Nevis had vervangen, bleef zijn ambt uitoefenen tot omstreeks de helft van 1819.

Een persconflict leidde ertoe, dat bij arrest van het hof het eenige blad, de Gazette de Gustavia, eigendom van een kleurling, gedwongen werd voortaan zijn inhoud ter gouvernementssecretarie te laten censureeren.

De nieuwe gouverneur was John Nordeling. Hij was geen onbekende, daar hij op St. Barthélémy voorzittervan het hof van justitie was geweest. Algemeen was de vreugde, waarmee hij ontvangen werd. De vice-gouverneur vroeg ontslag en vertrok naar $Z$ weden.

21 September 1819 teisterde een orkaan, die herinneringen opriep aan die van 1772, en 56 huizen en vele schepen verwoestte. Op St. Martin en op St. Eustatius was het nog veel erger. Op eerstgenoemd eiland telde men 300 dooden, en St. Eustatius werd geheel verwoest.

De bevolking bestond in die dagen uit: in Gustavia 719 blanken, 713 vrije negers en kleurlingen en 1748 slaven, tezamen 3180 inwoners; in de buitendistricten 1019 blanken, 103 kleurlingen en 555 slaven, tezamen 1677 inwoners. Op het heele eiland woonden dus 4857 personen. Deze cijfers zijn te belangwekkender, als men bedenkt, dat vóór de komst der Zweden het eiland voornamelijk bewoond werd door een kolonie van Normandiers, die - ook nu nog - hun voorvaderlijke zeden bewaard hebben en zich noch met blanken van anderen stam noch met kleurlingen vermengd hebben. Steeds hebben deze Normandiërs de kern der bevolking uitgemaakt. In de stad bestond de blanke bevolking uit lieden van allerlei Europeesche nationaliteit, die kwamen, als de handel bloeide, en gingen, als deze in verval was. 
Hier volgen nog eenige vergelijkende bevolkingscijfers:

$$
\text { in de stad }
$$

18005000 inwoners;

18121000 blanken, 1000 vrij- 930 bl., 90 vr. kleurlingen; en van de kleur;

1819700 blanken, 700 vrije 1000 blanken, 100 vr.kl.; kleurlingen;

1935300 inwoners, meer kl. $\quad 2000 \mathrm{bl}$., enkele kl. dan bl.;

De schade, door de orkaan toegebracht, was in 1820 weer hersteld. Langzamerhand komen weer enkele schepen de haven binnenvallen. Over de kooplieden van St. Thomas is men niet te spreken. De gouverneur zal wel de meening van de bevolking hebben uitgedrukt, toen hij hen noemde ,honden op een handvol stroo". J. Haasum was de nieuwe burgemeester, tevens gouvernements-secretaris.

Dan is het vooral de buitenbevolking, die veel te lijden heeft van het uitblijven van de regen. Tot September duurde de droogte. De geweldige regens, die toen losbraken, brachten het einde van de ellende niet; een kwaadaardige koorts tastte bijna ieder aan en maakte veel slachtoffers. De gouverneur verloor drie van zijn kinderen, onder welke zijn oudste zoon, die bestemd was voor de secretarispost.

Gouverneur Nordeling was een bekwaam man, gelijkmatig van humeur, levendig en vroolijk, waardoor hij aller achting wist te winnen.

Misschien doordat ook vele soldaten gestorven waren aan de koorts, werden in 1820 twee lichtingen opgeroepen, een van blanken en een van kleurlingen, elk 250 man sterk. Een treurige gebeurtenis onder het garnizoen was de moord op luitenant Frédrik Ivon Platin door sergeant Andersson, die onder invloed van sterke drank schijnt gehandeld te hebben. De dader werd ter dood veroordeeld, en door den vrijgelaten slaaf James Duck opgehangen.

Er was in dezen tijd in Gustavia een geweldige ophooping van koopwaar, gelijk in alle naburige vrijhavens, waardoor tegen spotprijzen verkocht moest worden. Het was de tijd, waarin de Zuid-Amerikaansche Spaansche koloniën haar vrijheid bevochten; ook van die landen kwam een toenemend aantal zeeschuimers de Caraïbische zee onveilig maken. Nordeling weigerde hun den toegang tot de baaien, als zij geroofd goed bij zich hadden, tenzij zij zware averij beloopen hadden, die dringend hersteld 
moest worden. Voor deze wetsovertreders was het echter geen bezwaar om onder Amerikaansche of Hollandsche vlag binnen te komen en groote hoeveelheden van allerlei artikelen aan den man te brengen, wat den handel geen kwaad deed, en van hooger hand door de vingers gezien werd. Zoo werd van de laatste tien jaren 1821 nog het gunstigste. Zelfs kon de kolonie nog heel wat geld naar het moederland zenden.

Het bleef zoo niet. In September van het genoemde jaar teisterde weer een hevige cycloon het eiland. Magazijnen, de Wesleyaansche kerk en een groot aantal negerhutten werden verwoest. De gouverneur verliet juist op tijd, 's nachts om twee uur, zijn villa, die bij de batterijen op de heuvels lag; nauw had hij deze verlaten, of het huis ,ging naar den duvel”, om zijn eigen woorden te gebruiken. Van de Amerikaansche schepen alleen reeds gingen er elf verloren.

De handel ging in 1822 achteruit. Wel werd orde geschapen in het muntstelsel; het Noord-Amerikaansch en Engelsch-koloniaal geld werd aan de circulatie onttrokken. Voor St. Barthélémy, dat een zekeren naam had gekregen als doorvoerhaven, was noodlottig het besluit van het Engelsche parlement om de havens in de Engelsche koloniën open te stellen voor den Amerikaanschen handel.

Wederom trad na de cycloon een tijdvak van droogte in, dat voor alle Antillen verschrikkelijk was. De oogst mislukte, en aan koffie en suiker kwam gebrek. Intusschen werd aan de zoutexploitatie, die allengs op het doode punt gekomen was, nieuw leven ingeblazen door zekeren dr. Lüren en den koopman J. Bernier.

Eindelijk werd in dezen tijd her verzoek om stemrecht voor de kleurlingen bij verkiezingen voor de Conseil du gouvernement ingewilligd.

Een conflict tusschen den gouverneur en een deel der invloedrijke kooplieden, gesteund door ondergeschikte ambtenaren, leidde tot een klacht bij den Koning tegen zijn vertegenwoordiger, maar de gouverneur won het pleit.

Het voortdurende terugloopen van den handel bracht Nordeling tot het voorstel om de koloniale begrooting ten aanzien van drie posten te verlichten: het traktement van den gouverneur zou van 7000 op 5000 piaster gebracht worden; het banket bij gelegenheid van 's Konings verjaardag zou afgeschaft worden; de Luthersche predikant zou ontslagen worden, want het garnizoen en de Zweden op het eiland konden zich begeven naar de 
diensten aan boord der oorlogsschepen, of wel de godsdienstoefeningen in de Methodisten kerk bijwonen.

Ook nam de gouverneur maatregelen om het wettig huwelijk voor katholieken, hoofdzakelijk de plattelandsbevolking, gemakkelijker te maken. Hij wenschte een einde te maken aan allerlei onwettige samenleving, die bevorderd werd, doordat er, dikwijls met groote tusschenpoozen, slecht doortrekkende katholieke priesters op het eiland kwamen. Er werd een commissie van burger-officieren, die de gouverneur „kapiteins van de kwartieren" noemde, ingesteld, die als ambtenaren van den burgerlijken stand zich ervan moesten overtuigen, dat ze toekomstige echtelieden ,acte de présence" in de kerk gegeven hadden, en dan geschiedde de afkondiging van het voorgenomen burgerlijk huwelijk. Voor den gouverneur, hun ouders en de getuigen werd dan trouw gezworen, waarna de gouverneur bruid en bruidegom het recht gaf, om hun huwelijk, door den eersten priester, die het eiland aandeed, te laten inzegenen. De katholieken waren ingenomen met deze regeling, en Nordeling kreeg den naam, dat hij een beschermer van den katholieken godsdienst was. Hij wenschte ook, dat een priester zich op het eiland zou vestigen, die dan tevens een goede schoolmeester zou kunnen zijn voor de onontwikkelde katholieke bevolking buiten de stad.

De school, die onder de bescherming van de Methodisten kerk stond, was goed in orde. Bij een examen in 1824 ondervroeg de gouverneur zelf verschillende leerlingen, en zoowel negers als mulatten gaven hem zeer goede antwoorden.

Met de geldmiddelen was het nu zoo ver gekomen, dat de inkomsten de uitgaven niet meer konden dekken.

De handelscrisis bereikte in 1825 het hoogtepunt. De handel zag niets meer in St. Barthélémy en gaf de voorkeur aan Portorico, waarheen veel kooplieden verhuisden. Het kwam zelfs zoo ver, dat de ambtenaren hun salaris niet meer in ontvangst konden nemen. Het volgende staatje geeft een indruk.

\section{I n k o m s t e n}

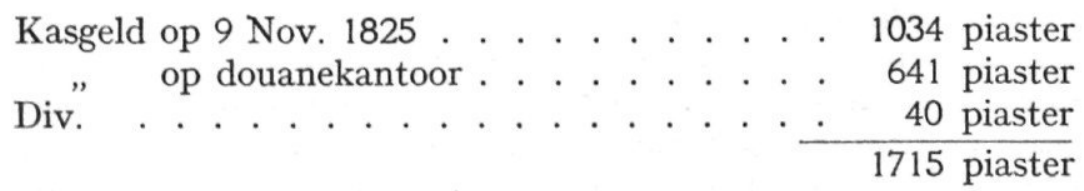




\section{Uitg a ven}

Nadeelig saldo 1ste trim. . . . . . . . . . 922 piaster

Tractem. 2de en 3de trim. . . . . . . . . . 4749 piaster

Tractem. 4de trimester . . . . . . . . . 3022 piaster

Uitg. voor garn. ,mil. etc.. . . . . . . . . $\frac{260 \text { piaster }}{8953 \text { piaster }}$

1715 piaster

Tekort . . . . . . . . . . . . 7238 piaster

Nordeling, die persoonlijk veel onaangenaamheid ondervond van de voortdurende kuiperij van het handelshuis Bigard, bestuurd door een niet-blanke familie, die van vader op zoon steeds het gouvernement vijandig was geweest, trok zich allengs terug in een ambteloos leven. Drie jaren later stierf hij onder tragische omstandigheden. Op een rit te paard was hij juist op de hoogte van fort Gustave III gekomen, toen de schildwacht brand in de stad ontdekte. De man deed hetgeen hem bevolen werd en liep naar een kanon, dat hij liet losbranden om de aandacht der bewoners op de brand te vestigen. Het paard van Nordeling schrok geweldig, maakte een sprong, zoodat de berijder uit het zadel werd geslingerd en terecht kwam in een diepte langs den weg, vol keien en rotsblokken. Toen hij opgenomen werd, bleek hij een zware schedelbreuk te hebben. Het gebeurde niet ver van des gouverneurs woning in quartier public. Daarheen werd hij vervoerd, maar weldra overleed hij. Hij werd begraven op het kerkhof in L'Orient, in de schaduw van de R.K. kerk, die onder zijn bestuur gebouwd was (sinds 1905, de confiscatie is deze kerk de openbare school). Op dit kerkhof, en niet in de stad, is de upper ten der Zweden begraven.

Haasum, de burgemeester, werd gouverneur ad interim.

De bevolking was zeer verminderd. Er waren in 1825 nog maar 4016 inwoners, waarvan 1723 blanken, 906 vrije kleurlingen en 1387 slaven. De bevolking leefde van vischvangst en veeteelt. Het kweeken van katoen was opgegeven, omdat dit artikel geen prijs meer opbracht op de markt. Nordeling had in zijn tijd de druivencultuur zeer aangemoedigd en daartoe zelfs wijnstokken laten komen van Madeira, maar ook dat haalde niets uit tengevolge van de droogte en de geringe vruchtbaarheid van den grond. $\mathrm{Nu}$ nog staan in het witte strandzand massa's verwilderde druiven.

In het volgend jaar leefde de handel wat op, en in 1827 was het nog beter. Vele groote schepen, hoofdzakelijk met Noord-Ameri- 
kaansche producten, zag men in de haven. Er zal dan ook wel wat naijver hebben voorgezeten bij den Franschen admiraal Bergeret, de kommandant van het eskader in de Antillen, die den gouverneur van St. Barthélémy ervan beschuldigde een zeeroover gelegenheid te hebben gegeven zijn prijs te verkoopen. Haasum kon zich echter met goed gevolg tegen dezen aanval verdedigen. Gaf hij aldus blijk van de gebeurtenissen buitengaats op de hoogte te zijn, de dingen binnengaats vorderden ook zijn aandacht.

De verhouding tusschen de blanke en de gekleurde bevolking was lang niet goed, en in den laatsten tijd werd het steeds erger. Vechtpartijen, bloedige vechtpartijen zelfs, vonden plaats om luttele redenen. Het waren vooral de blanken van het land, de Normandiërs, die, vol vooroordeel en opgesloten in een clangeest, zich het bestaansrecht van een ander ras niet konden indenken.

De toestand van den handel in de jaren 1829 en 1830 was, hoewel niet zoo gunstig als in het jaar ervóór, toch niet slecht te noemen. Echter nam de Engelsche handel op Amerika toe, en dat was voor St. Barthélémy een zware slag; weder verlieten veel vreemde kooplieden het eiland voor goed.

Haasum ging in 1831 met verlof naar Zweden; Morsing, die feitelijk met Haasum samen het gouvernement had waargenomen, bleef alleen op zijn post. In 1833 was Haasum terug en ging Morsing met verlof.

Carl Ulrich wordt genoemd als gouvernementssecretaris.

De predikant Carlson had in 1831 een jongensschool geopend in Gustavia, in twee klassen verdeeld. In de eerste klas werd onderwezen de geschiedenis van Zweden, Engelsche taalleer, Bijbelsche geschiedenis, rekenen en aardrijkskunde. De tweede klas kreeg onderwijs in Fransch, catechese, meetkunde, aardrijkskunde, algemeene geschiedenis, Zweedsch, algebra en Latijn. De onderhoudskosten van de school werden bestreden door vrijwillige bijdragen, schoolgelden en een jaarlijksche ondersteuning van den Koning, groot 100 piaster.

Ook een meisjesschool werd door ds. Carlson geopend. Aan de methodistenschool vond hij nl. niets goeds. De onderwijzeressen daarvan hadden volgens hem niet de minste paedagogische kennis en ervaring, noodig voor verstandelijke en zedelijke ontwikkeling van de jeugd. Zelfs noemde hij haar „oude marktwijven”.

Haasum erkende het in een particulieren brief aan een vriend, dat de handel heel weinig meer te beteekenen had. Er werd veel 
ellende geleden; velen kwamen tot de bedelstaf. Om de zaken in evenwicht te houden moest de gouverneur maar al te veel de gelden aanspreken, die de Koning bij de Londensche bank had geplaatst tot ondersteuning der kolonie. Het bevolkingscijfer liep terug tot 3720 inwoners, nl. 2080 in Gustavia en 1640 op het land.

De jaren 1835 en 1836 gingen zonder bijzonderheden voorbij; de handel zonk nog dieper. Men sukkelde voort, totdat 2 Augustus 1837 een geweldige orkaan de ellende kwam vermeerderen. Tweehonderd huizen werden geheel verwoest, meer dan 100 ernstig beschadigd. Wat erger nog was - men telde 40 dooden en 30 gewonden. Het gouvernementspaleis was er van de openbare gebouwen het ergst aan toe. De gouverneur en zijn familie moesten vluchten en konden nog juist hun leven redden. De katholieke kerk in de stad en de Zweedsche kerk werden ernstig beschadigd. Het land had minder van de orkaan geleden. Hulp, vooral geldelijke hulp, werd weldra door de naburige eilanden geboden. De Zweedsche koning zond 100 pond sterling ten bate der slachtoffers. Maar men sloeg de handen dadelijk weer aan het werk, en althans het noodzakelijke werd herbouwd of hersteld. Ook kwam er de volgende jaren wat meer leven in den handel. In 1839 bezochten 59 Zweedsche, 52 Amerikaansche, 251 Engelsche, 33 Fransche, 7 Deensche, 8 Spaansche, 54 Nederlandsche schepen en één Columbiaansch schip de haven.

In 1840 stierven niet minder dan drie- à vierhonderd personen aan een kwaadaardige koorts. Bijna alle ambtenaren werden aangetast; de ontvanger Plagmann en Lyon, de kommandant der batterij, verloren hun echtgenooten; Abott, de chef van de douane, liet met zijne vrouw het leven de twee dokters van het eiland, Lüren en Mason, waren zelf ziek. Weldra telde het eiland niet meer dan 2535 zielen. De zoutoogst bracht het tot slechts 3000 vaten. Na een kortstondige verbetering in den gezondheidstoestand brak de epidemie opnieuw uit. Haasum vertrok met ziekteverlof en keerde eerst in 1842 terug.

1843 is bekend als het jaar eener verschrikkelijke aardbeving in het Antillengebied. Gelukkig leed St. Barthélémy niet erg, maar op Guadeloupe telde men de slachtoffers bij duizenden.

Het volgend jaar kreeg de gouverneur verlof om naar Zweden terug te keeren, en Ulrich werd zijn plaatsvervanger. In dezen tijd werd voor goed een katholiek priester benoemd om twee parochies waar te nemen op het eiland; tevoren waren deze toegewezen aan den pastoor van St. Martin, die maar af en toe had kunnen overkomen.

(Wordt vervolgd)

West Indische Gids XVII 